\title{
Habitação pública e modernização capitalista: uma relação dialética entre fontes de pesquisa e procedimentos de análise
}

\section{Nilce Aravecchia-Botas ${ }^{2}$}

RESUMO: Este artigo pretende contribuir com uma reflexão metodológica acerca da história da habitação no Brasil, mais especificamente no que diz respeito ao início da ação estatal no setor. Os procedimentos de análise e as formas de mobilização das fontes utilizadas para o trabalho de doutorado realizado pela autora serão postos em tela com o objetivo de evidenciar as escolhas metodológicas que serviram para interpretar a produção pública de habitação entre 1930 e 1964, bem como sua relação com a constituição do sistema capitalista no Brasil. Tal esforço insere-se no trabalho coletivo de pesquisa do Grupo Pioneiros da Habitação Social no Brasil, coordenado por Nabil Bonduki, que realizou amplo levantamento de conjuntos habitacionais construídos no período em questão, e revelou uma diversidade de soluções arquitetônicas e urbanísticas. Devido à natureza do objeto de pesquisa, o grupo entrou em contato com várias fontes documentais que originaram um acervo extenso e diversificado em sua base material. Explorar, interpretar e construir abordagens historiográficas a partir desse acervo é tarefa que ainda não se esgotou. A análise apresentada se justifica diante da complexidade do objeto empírico e de sua inserção num momento crucial para o processo histórico brasileiro.

PALAVRAS-CHAVE: História da habitação. Habitação social. Processo de urbanização.

ABSTRACT: This article intends to contribute a methodological reflection on the history of housing in Brazil, specifically in regard to the beginning of state action in the sector. The analysis procedures and ways of mobilization of the sources used for the doctorate work of the author will be put on display in order to highlight the methodological choices which served to interpret the public housing production between 1930 and 1964, and its relationship to the establishment of the capitalism in Brazil. This effort is part of the collective work of research of the Group Pioneers of Social Housing in Brazil, coordinated by Nabil Bonduki, which produced a comprehensive survey of housing built in the period, and revealed a diversity of architectural and urban solutions. Due to the nature of the research object, the group contacted several documentary sources that originated an extensive and diversified collection in its material base. To explore, to interpret and to build historiographical approaches from this collection is a task that has not been exhausted.
1. Este artigo é uma versão reformulada do texto apresentado no III Enanparq Arquitetura, cidade e projeto: uma construção coletiva (2014).

2. Arquiteta e urbanista, docente da graduação e da pós-graduação da Faculdade de Arquitetura e Urbanismo da Universidade de São Paulo (USP). E-mail: nilcearavecchia@usp.br. 
3. Com a instituição do Ministério do Trabalho pelo governo Vargas em 1933, iniciou-se a criação dos institutos de previdência por categoria profissional obedecendo a seguinte ordem cronológica: Instituto de Aposentadoria e Pensões dos Marítimos (IAPM) em 1933; Instituto de Aposentadoria e Pensões dos Bancários (IAPB) e Instituto de Aposentadorias e Pensões dos Comerciários (IAPC) em 1934; Instituto de Aposentadoria e Pensões dos Industriários (Iapi) em 1937 , entrando em funcionamento apenas em 1938; e o Instituto de Aposentadoria e Pensões dos Empregados em Transportes e Cargas (Iapetec), que integrou todas as Caixas de Aposentadoria e Pensões (CAPs) dos trabalhadores do setor de transportes e cargas em 1938.

4. Entre 1930 e 1964 o Poder Público financiou 175.060 unidades habitacionais. Dentre essas, 98.854 foram construídas diretamente pelo Estado por meio dos órgãos de previdência, dos órgãos locais de produção habitacional (municipais e estaduais) e da Fundação da Casa Popular - instituição federal criada com a função precípua de financiamento e construção habitacional que funcionou entre 1946 e 1964 . No caso da outra parte, o Estado financiou a aquisição ou a construção de moradias, que ficava a cargo do próprio morador.

5. A publicação Os pioneiros da habitação social no Brasil foi resultado dos desdobramentos da pesquisa que Nabil Bonduki realizou no âmbito de sua tese de doutorado entre 1987 e 1995. O avanço na temática em outras duas etapas envolveu uma grande equipe de pesquisadores, entre eles alunos de graduação e de pós-graduação da Escola de Engenharia de São Car-
The analysis presented is justified by the complexity of the empirical object and its insertion in a crucial moment for the Brazilian historical process.

KEYWORDS: History of housing. Social housing. Urbanization process.

A partir de 1930 no Brasil se iniciou de maneira mais efetiva a participação do Estado na produção de habitação social. Esse processo foi reconhecido como o início da ação estatal, mas não foi considerado como política pública em sentido pleno, por não ter alcançado resultados quantitativos que apontassem para a universalização do acesso à moradia (BONDUKI, 1998). Este artigo dialoga com essa interpretação, mas faz uma reflexão sobre os métodos utilizados para a análise do objeto empírico los conjuntos habitacionais produzidos entre 1930 e 1964), e elabora novas questões históricas a partir de referenciais teóricos distintos. Nesse sentido, a pergunta não se coloca sobre a efetividade da produção como resposta à demanda habitacional, mas sobre o que significou historicamente, a partir de contexto socioeconômico bem específico, o resultado dessa produção como parte de um projeto político que considerava o processo de urbanização como elemento para sua implementação. A partir do levantamento empírico mais extenso de toda a produção habitacional do período, financiada por órgãos municipais e, principalmente, pelos órgãos federais de previdência, os Institutos de Aposentadorias e Pensões (IAPs), ${ }^{3}$ subordinados ao Ministério do Trabalho, foi o recorte na ação do Instituto de Aposentadoria e Pensões dos Industriários (lapi) que ensejou uma nova reflexão.

Até o ano de 1964, foram construídas cerca de 100 mil unidades habitacionais pelo setor público no Brasil, ${ }^{4}$ e do ponto de vista da arquitetura e do urbanismo, essa produção, que à primeira vista foi relacionada às manifestações da arquitetura moderna, acabou surpreendendo pela diversidade de resultados estéticos e espaciais que promoveu. Nos inúmeros conjuntos habitacionais pode-se confrontar diretamente paradigmas habitacionais, como o de pequenos conjuntos de casas isoladas no lote com telhado em águas e o do grande edifício prismático de moradia coletiva, que comporta também serviços públicos e comércio. Num olhar mais panorâmico sobre essas realizações, destacam-se os exemplos híbridos que congregam essas soluções aparentemente díspares (Figuras 1-6). A grande diversidade de tipos edificados pode ser observada no segundo volume da coleção "Pioneiros da Habitação Social", publicada em 2014. A coleção em três volumes foi o principal resultado de quinze anos de investigação que envolveu inúmeros pesquisadores em várias etapas, em grupo de pesquisa coordenado por Nabil Bonduki, desde 1997.5 Além desse grande compêndio que sistematizou e deu maior publicidade ao trabalho do grupo, várias pesquisas acadêmicas individuais deram origem a dissertações de mestrado, teses de doutorado, livros e artigos científicos. 

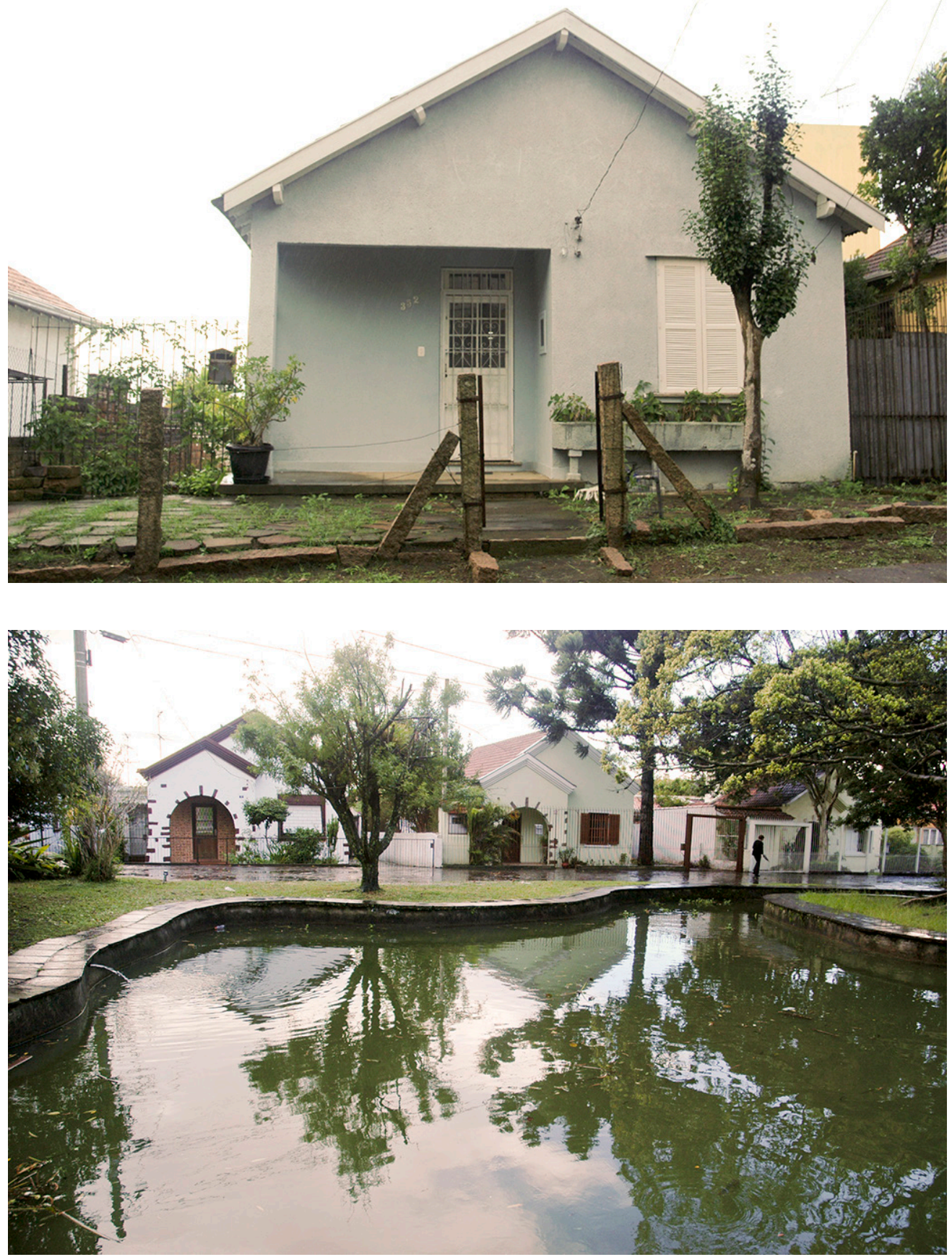

Figuras 1 e 2 - Conjunto Residencial Passo D'Areia, Porto Alegre. Tipos de casas isoladas no lote, com recuos laterais e jardim frontal. A grande variedade de soluções desse empreendimento o torna um exemplo paradigmático da experimentação que caracterizou parte da ação habitacional do lapi. Importante destacar que a presença de um número significativo de casas isoladas nesse bairro da capital gaúcha divergia da diretriz do Instituto, que previa soluções mais adensadas para os maiores centros urbanos. Fonte: Acervo do Grupo Pioneiros da Habitação Social. los e da Faculdade de Arquitetura e Urbanismo, ambas da USP, além de colaboradores de outras instituições. A primeira etapa, realizada entre 1997 e 2001, foi parte do projeto temático da Fundação de Amparo à Pesquisa do Estado de São Paulo (Fapesp), "Arquitetura Moderna e Habitação Econômica no Brasil (1930-1964)", sob a coordenação de Bonduki (então professor do Departamento de Arquitetura e Urbanismo da EESC USP) e de Maria Ruth do Amaral Sampaio, da FAUUSP. Nesse momento foram realizadas pesquisas mais extensas nos estados de São Paulo e Rio de Janeiro, onde se encontravam os principais arquivos públicos, e o maior número de empreendimentos realizados. A segunda etapa, de 2005 a 2010, realizada na FAU USP sob a coordenação de Bonduki, teve apoio da Fapesp e financiamento por meio da Lei de Incentivo à Cultura, possibilitando estender a pesquisa para outros estados, alcançando-se abrangência nacional, chegando-se então à documentação de 385 conjuntos habitacionais, em 81 municípios situados em 24 unidades da federação. Ver Nabil Bonduki; Ana Paula Koury (2014, p. 4-8). 


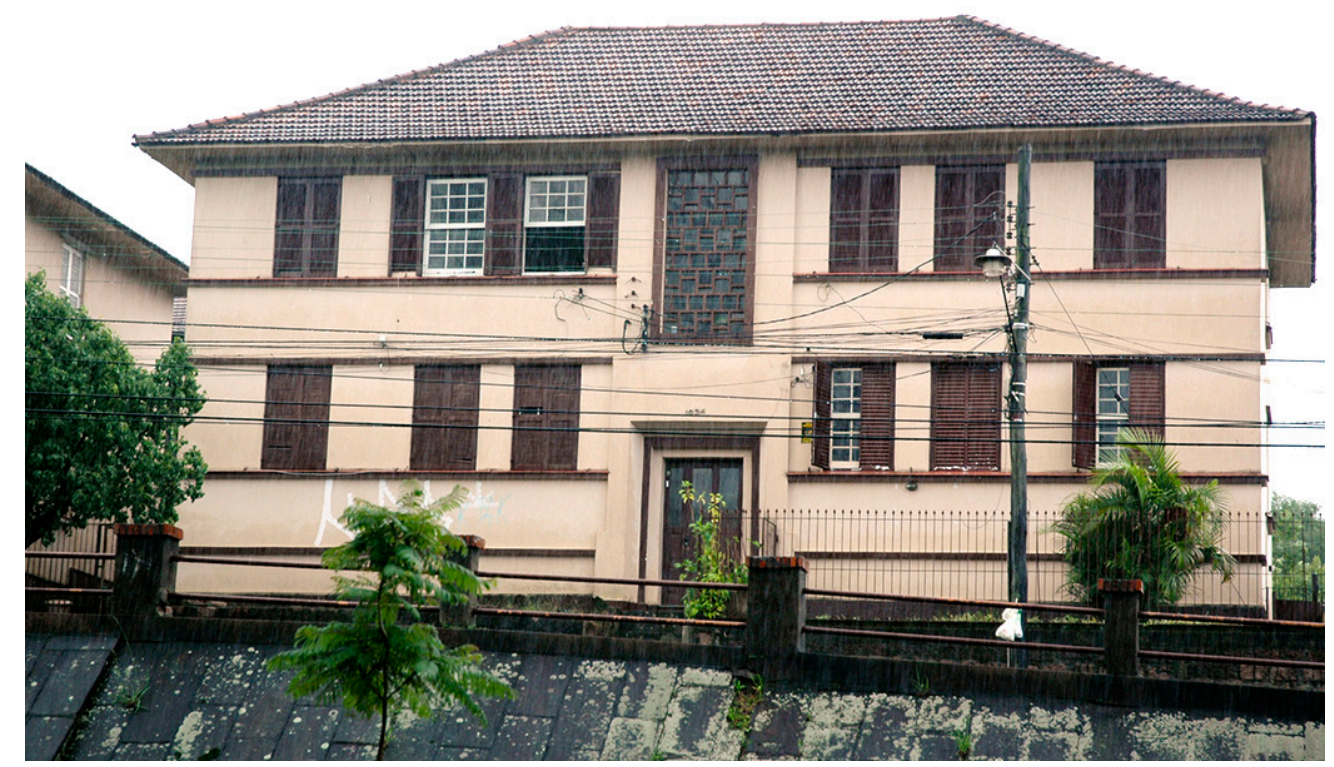

Figura 3 - Conjunto Residencial Passo d'Areia, Porto Alegre. Exemplo de um dos tipos de bloco de habitação coletiva, entre vários outros existentes no conjunto. Destacam-se uma contida ornamentação com os frisos acompanhando as janelas de madeira, a marcação de um pórtico na entrada com o elemento vazado envidraçado na abertura que ilumina a circulação vertical e o telhado em quatro águas, que, compondo com o traçado sinuoso das ruas do conjunto, the confere a paisagem pitoresca. Fonte: Acervo do Grupo Pioneiros da Habitação Social.

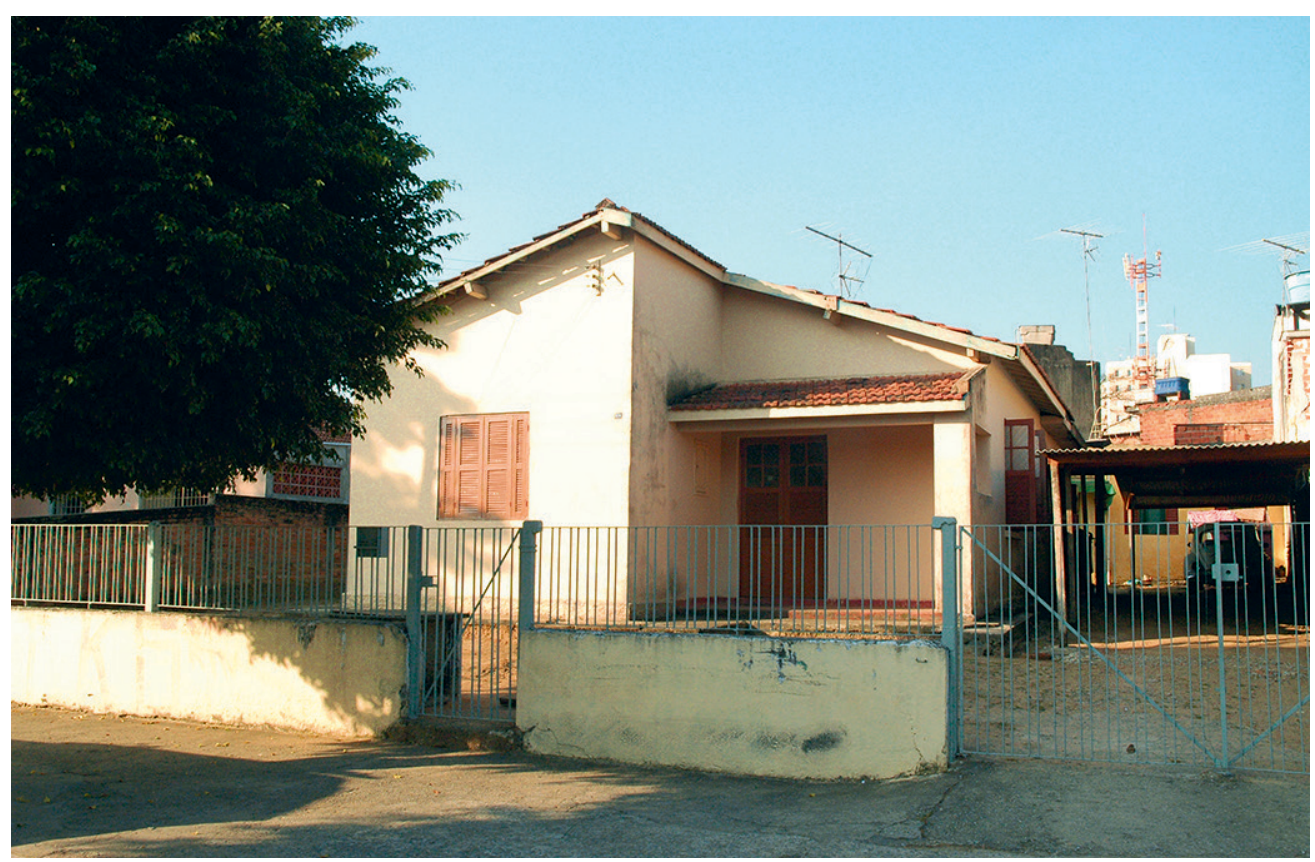

Figura 4 - Conjunto Residencial Piratininga, Osasco (SP). Nas casas isoladas a volumetria simplificada, encerrada por duas águas, é quebrada apenas pelo telhado inclinado da varanda. A solução concilia as formas mais abstratas de quebras geométricas, com 0 telhado tradicional em cumeeira, típica experimentação da Divisão de Engenharia do lapi, sob a chefia do arquiteto Carlos Frederico Ferreira. Fonte: Acervo do Grupo Pioneiros da Habitação Social. 


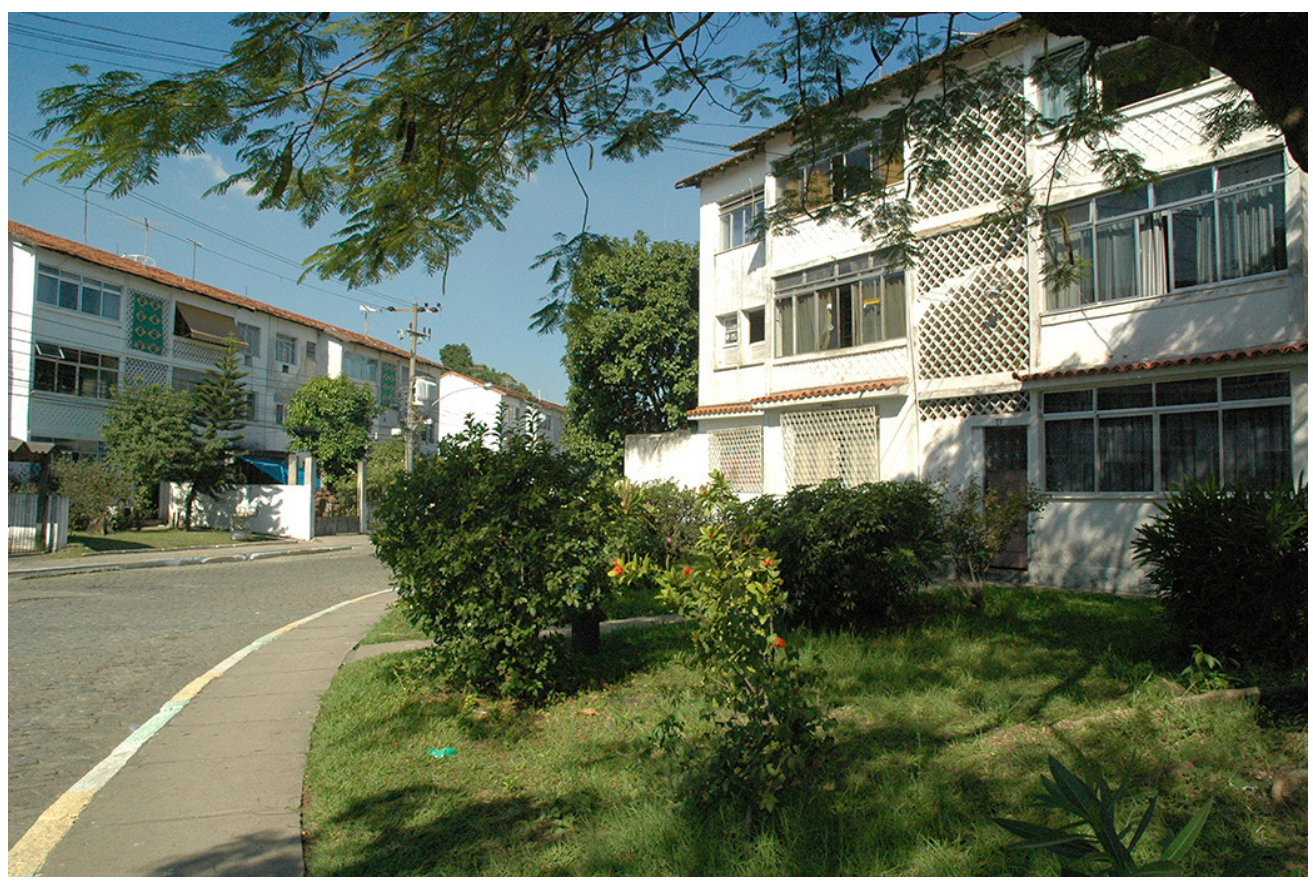

Figura 5 - Conjunto Residencial Moça Bonita, Rio de Janeiro. Esse empreendimento é conformado apenas por esse tipo de bloco de habitação coletiva. As paredes da circulação vertical, vedadas com elementos cerâmicos vazados (os cobogós), e os telhados em duas águas aproximam a solução formal do edifício das imagens que foram usualmente atribuídas à arquitetura moderna carioca, desenvolvida nas décadas de quarenta e cinquenta. Fonte: Acervo do Grupo Pioneiros da Habitação Social.

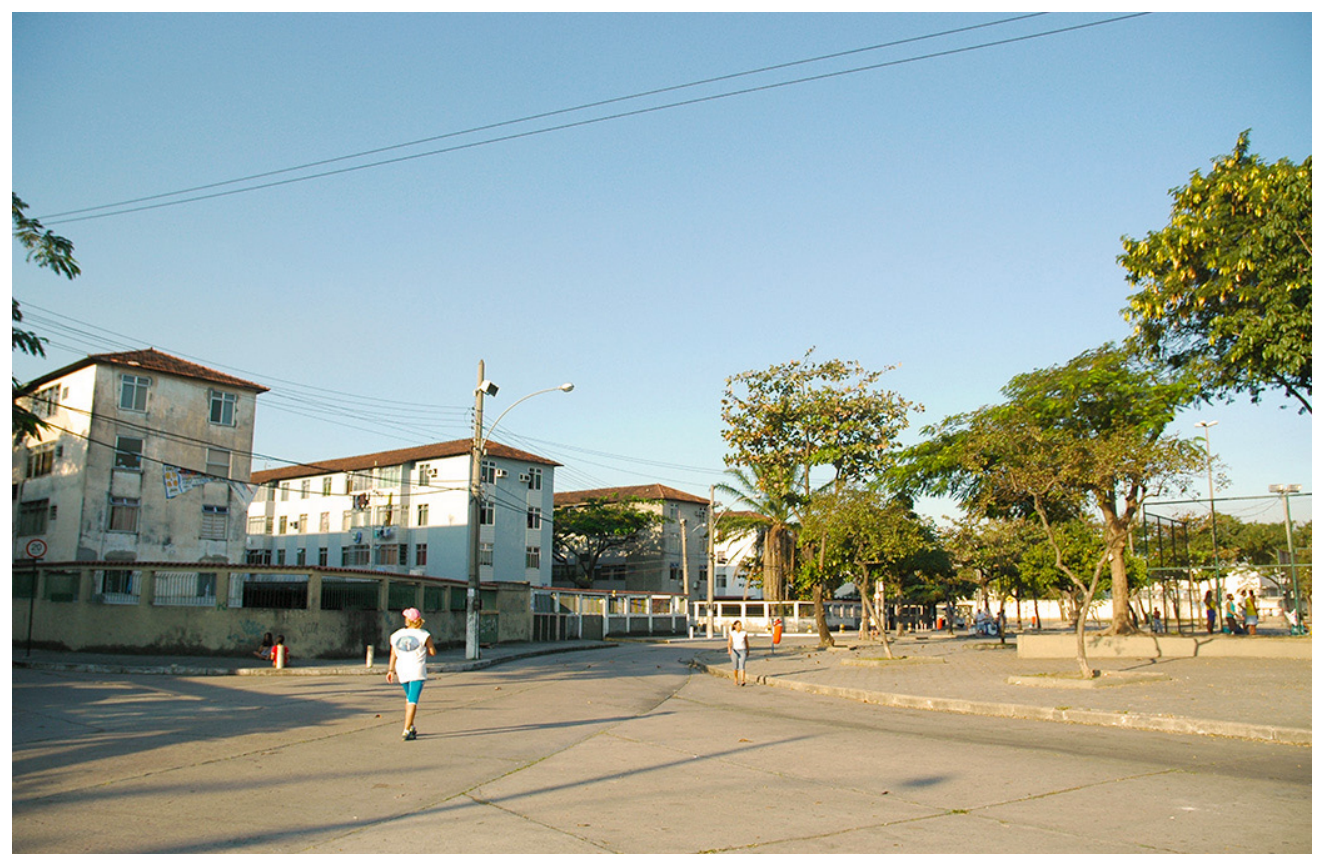

Figura 6 - Conjunto Residencial da Penha, Rio de Janeiro. Esse empreendimento teve um primeiro projeto em 1940 de autoria dos Irmãos Roberto, o que não foi levado a termo. Ao final da década de quarenta, o conjunto foi construído seguindo projeto elaborado pela equipe da Divisão de Engenharia do lapi. Os edifícios representam, em certa medida, o que foi a solução mais pragmática adotada pelos engenheiros do Instituto, com vedação em alvenaria convencional e fechamento em telhado de quatro águas. Fonte: Acervo do Grupo Pioneiros da Habitação Social.

Annals of Museu Paulista. v. 24. n.3. Sept.-Dec. 2016. 
6. Essa fonte, entretanto, demandou grande esforço de identificação das peças gráficas, já que para o INSS essa documentação é parte de processos em curso, de regularização e de posse das unidades habitacionais, e conta com desenhos originais de conjuntos construídos e não construídos, indiscriminadamente reunidos a projetos de reforma de partes das edificações ou de unidades habitacionais específicas.

7. O volume II da coleção Os pioneiros da habitação social no Brasil, intitulado "Inventário da produção pública no Brasil entre 1930 e 1964", traz o panorama completo da produção de moradias no período, seguindo essa divisão. Para proporcionar uma leitura satisfatória, as peças gráficas relativas aos projetos arquitetônicos foram redesenhadas para a publicação, de forma a uniformizar escalas e permitir análises comparativas. Ver Bonduki; Koury (2014, v. II.).

8. O acervo encontra-se abrigado temporariamente no Instituto Casa da Cidade, aguardando resolução para ser transfe-rido para alguma instituição pública.
Esses trabalhos se valeram de um acervo constituído ao longo dos anos, a partir de extensos levantamentos junto aos periódicos de época, que forneceram peças gráficas dos projetos arquitetônicos, fotos de maquetes e de conjuntos habitacionais recém-inaugurados. Tais periódicos, tanto os editados pelos organismos oficiais com algumas seções que publicavam os projetos públicos, quanto os especializados, editados por sociedades de classe, agremiações estudantis e editoras privadas, traziam textos e memoriais descritivos que em sua maioria exaltavam as realizações desses conjuntos habitacionais. Por meio dessas publicações também foi possível identificar algumas das autorias dos projetos. Outra rica fonte de pesquisa foram os arquivos do Instituto Nacional de Seguridade Social (INSS) no Rio de Janeiro, que reúnem o material que pertencia às diversas delegacias centrais dos institutos de previdência. ${ }^{\circ} O$ trabalho de campo deu origem à parte do material de desenho - quando eram escassos ou inexistentes os documentos de alguns empreendimentos - e à complementação do acervo fotográfico, tanto aquele contemporâneo à pesquisa, quanto ao extraído de álbuns de família dos antigos moradores. O material foi por fim sistematizado em acervo físico e digital, e está dividido por órgãos promotores, por empreendimento e por tipo de documentação (desenhos, fotos de época da construção, fotos contemporâneas à pesquisa).?

A partir de um olhar panorâmico sobre esse acervo, ${ }^{8}$ entre a ação dos diversos órgãos estatais partícipes do processo, a produção do lapi já chamava atenção em diversos aspectos: os exemplares de exceção que em certa medida compreendiam o paradigma arquitetônico modernista; a quantidade de unidades habitacionais produzidas, que se sobressaía em relação aos outros órgãos; a presença significativa de arquitetos que transitavam com desenvoltura pelo meio profissional. Em relatório das atividades do lapi no ano de 1950, a arquitetura assumia papel protagonista, e a visão atuarial impunha a condição de que os edifícios construídos pelo Instituto deveriam "atender a padrões construtivos elevados, de forma a assegurar a permanente preservação da garantia imobiliária. Além disso, ficava estabelecido que as edificações projetadas deveriam atender às posturas municipais em vigor e traduzir, tanto quanto possível, empreendimentos de destaque no meio local da construção civil" (PEDRO, 1950, p. 289). Essa diretriz, cruzada com a presença de arquitetos reconhecidos pelo campo disciplinar, deu origem a edifícios emblemáticos que comunicavam o papel do Estado e do Instituto no processo de modernização das principais cidades brasileiras. É o que atesta, por exemplo, a arquitetura do Edifício Anchieta, de autoria dos Irmãos Roberto, no cruzamento da Avenida Paulista com a Rua da Consolação em São Paulo (SP), o qual desbravou a verticalização daquela região (Figura 7). Ou o Conjunto Residencial da Várzea do Carmo, de Atílio Correia Lima, localizado num ponto nodal entre a área central de São Paulo e os bairros operários localizados a leste (Figura 8). 


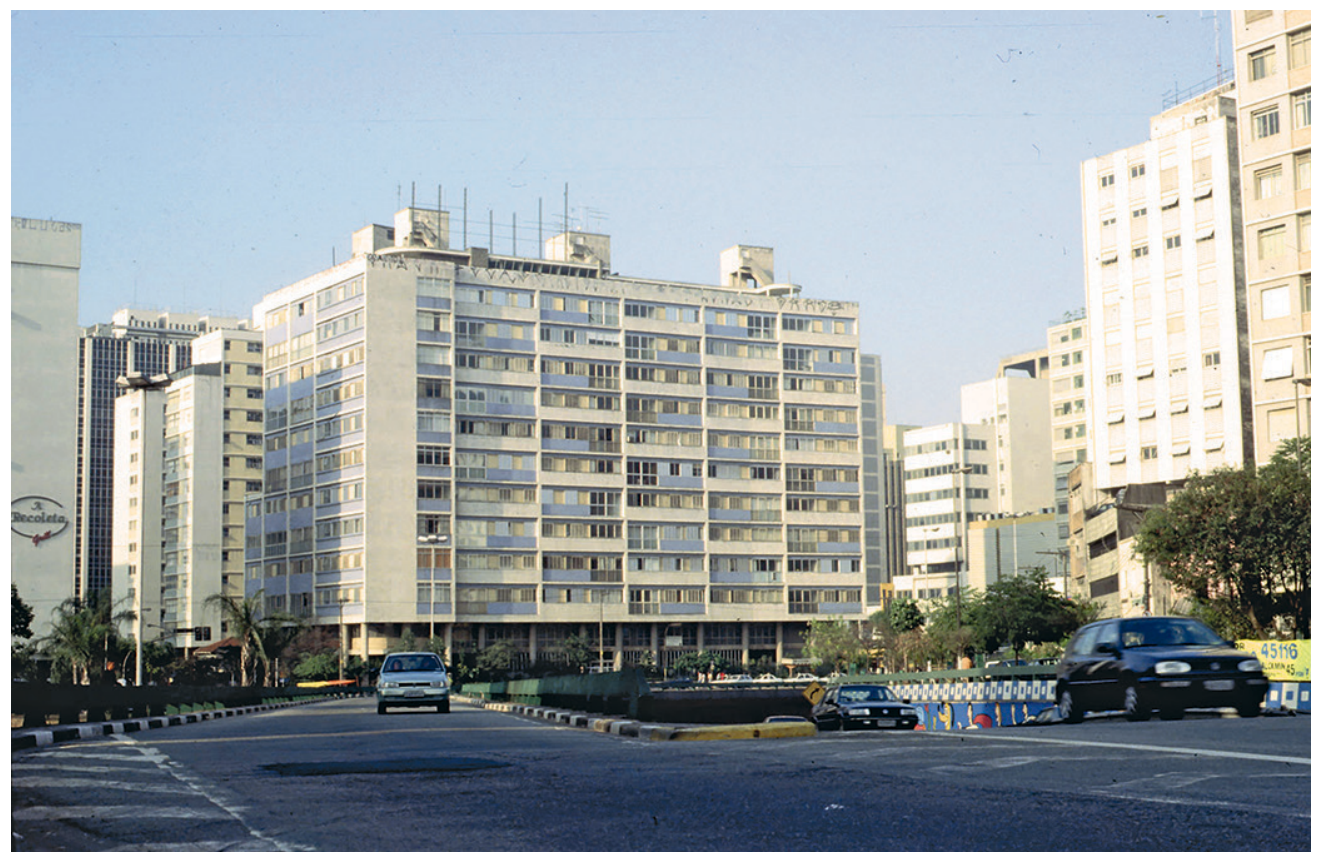

Figura 7 - Edifício Anchieta, São Paulo. Projeto dos Irmãos Roberto, representando a atuação do lapi na dinâmica imobiliária da metrópole paulistana. O edifício está localizado no cruzamento da Avenida Paulista com a Rua da Consolação. Fonte: Acervo do Grupo Pioneiros da Habitação Social.

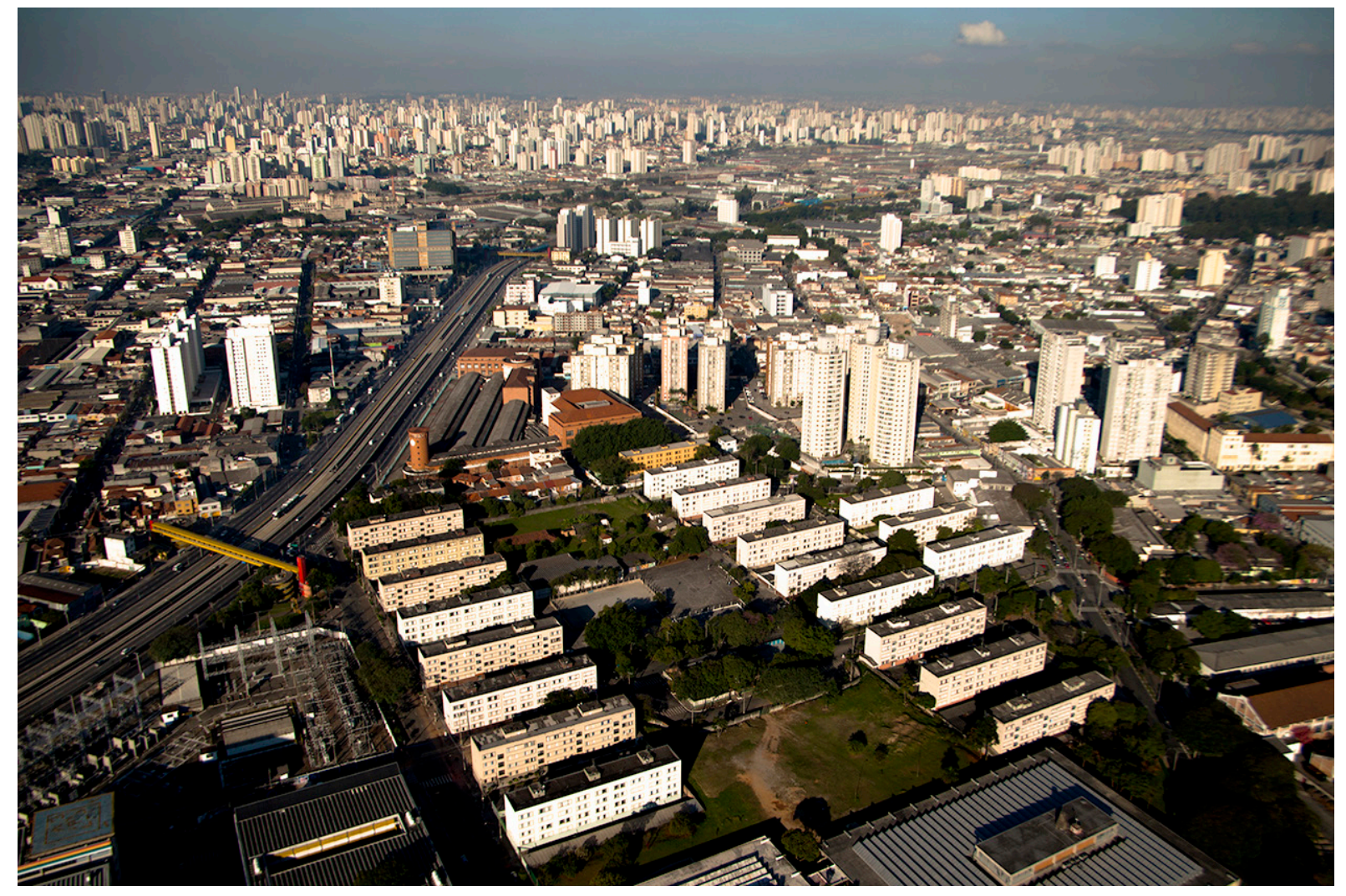

Figura 8 - Conjunto Residencial da Várzea do Carmo. Projeto de Áx́lio Correia Lima, incrustado na primeira área industrial da cidade, entre o Centro e a Zona Leste. Fonte: Acervo do Grupo Pioneiros da Habitação Social. 
A leitura construída neste artigo foi realizada sobre a produção específica do lapi, mas foi motivada pela dupla condição de quem auxiliou na construção e consolidação do acervo do Grupo Pioneiros durante mais de uma década, e depois dele se valeu como fonte de pesquisa (ARAVECCHIA-BOTAS, 2000, 2011 e 2014, p. 6-40; ARAVECCHIA-BOTAS; NASCIMENTO, 2014, p. 194-216). Nesse processo, a mobilização das fontes, realizada no âmbito da pesquisa de doutorado, oscilou entre circunscrevê-las ao universo restrito da produção arquitetônica ou inseri-las num todo maior. $\bigcirc$ objetivo foi destacar a inserção do lapi na produção habitacional pública do período estudado e pensar - papel dessa produção no processo histórico específico de consolidação da economia capitalista no Brasil. Por consequência, também se alternaram os métodos, já que, para pensar o processo histórico, eram necessárias análises mais macroestruturais, e para analisar os conjuntos habitacionais a demanda era por referenciais do campo disciplinar da arquitetura e do urbanismo. Assim, se o recorte do objeto, a produção habitacional do lapi, vinha definido pelas fontes, estabelecer os problemas que deveriam orientar a linha de análise foi um processo que demandou novo esforço.

Para Bonduki (1999), a história da habitação no Brasil, ainda que em sua maioria feita por arquitetos, até finais da década de 1990, havia se desenvolvido ao largo das discussões arquitetônicas, aproximando-se muito mais da economia, da sociologia e da antropologia. Nessa perspectiva, a maioria dos trabalhos sobre a temática se dedicou a analisar a ação do Estado com vistas a comprovar a ineficácia dos programas habitacionais e sua contribuição para a reprodução de um sistema excludente e segregador. No que diz respeito ao Estado varguista, deixou-se de considerar seu papel na modernização de uma sociedade rural e na transformação de um modelo político eivado pelo clientelismo (ARAVECCHIA-BOTAS; KOURY, 2014, p. 162).

Essa interpretação encontra parte da explicação no "antiestatismo da onda neoliberal", que, como evidenciou Adrian Gorelik, já havia antecipado a "demolição" dos conjuntos habitacionais de moradia social, encontrando eco, por um lado, na crítica sociológica de esquerda e, por outro, na crítica pós-modernista que reclamava a "identidade latino-americana" (GORELIK, 2005, p. 10-1 1). Centrava-se a crítica à modernidade na dimensão ideológica dos procedimentos técnicos da disciplina arquitetônico-urbanística, e em seu compromisso com o Estado modernizador e a dominação de classes. Por outro lado, as expectativas eram colocadas na organização mais autônoma da sociedade.

Tendo como horizonte uma abordagem interdisciplinar da história da habitação, era necessário colocá-la no campo de discussão da arquitetura e do urbanismo, levando em consideração as expressões mais populares de construção da cidade. Ao passar em revista sua própria trajetória, Bonduki assinala que, no início de sua pesquisa, aproximava-se muito mais dos enfoques macroestruturais de cunho marxista (influenciado pela sociologia urbana francesa da década de 
1970) e das abordagens foucaultianas com base no conceito de micropoder, e que, ao longo do seu trabalho, foi incorporando as análises estético-arquitetônicas. Assim, o resultado apresentado no livro Origens da habitação social no Brasil, publicado em 1998, era expressão dos dois momentos (BONDUKI, 1999). Nessa perspectiva, o livro apresentou um capítulo dedicado à produção arquitetônica supostamente vinculada às vanguardas modernistas, para o qual foi levantada apenas uma amostra inicial de conjuntos habitacionais promovidos pelo Estado entre 1930 e 1964, mas que apontava a existência de muitos outros. De fato, tal suposição se confirmou e, para além dos parcos exemplares publicados então, o esforço de inúmeros pesquisadores deu origem ao material empírico inédito já mencionado (BONDUKI; KOURY, 2014, v. II).

Se o estímulo a esse levantamento mais extensivo veio do interesse de reaproximação da questão habitacional ao debate arquitetônico, o imenso acervo produzido demonstrou que as realizações do período não estavam em total conformação com o movimento moderno. A arquitetura, como documento fundamental da pesquisa, parecia demandar a construção de um novo "problema", na acepção do programa defendido pelos Annales, para que se pudesse alcançar a interdisciplinaridade almejada para o aprofundamento da reflexão sobre os objetos (BLOCH, 2002; FEVBRE, 1977; LE GOFF, 1990). Nesse sentido, a análise das conexões culturais da arquitetura e do urbanismo apenas por meio de categorias marxistas, tal qual apropriadas pelo debate sociológico, bem como a leitura dos espaços como simples reveladores de estruturas disciplinares, não só se demonstrava insuficiente, como gerava anacronismos numa construção que não se pretendia isolada ao campo profissional da arquitetura e do urbanismo, mas também uma contribuição para o campo da história do país.

Ao reconduzir a discussão habitacional ao campo da arquitetura e do urbanismo, portanto, a proposta da análise sobre o lapi, aqui em foco, construiu também uma interpretação da história a partir de uma revisão crítica da vanguarda, escapando tanto dos velhos cânones modernistas quanto da crítica populista e da redução sociológica de esquerda às quais se referiu Gorelik (GORELIK, 2005). Foi então que se optou por ler a produção do período, e mais especificamente do lapi, na sua dimensão efetiva e na sua inserção no processo histórico. O sentimento de fracasso em relação à não universalização do acesso à moradia deu lugar à possibilidade de analisar o que de fato foi realizado, colocando em questão a produção habitacional como parte da consolidação da economia capitalista no Brasil, diante de condições históricas muito específicas.

Essa diretriz também permitiu analisar de forma mais complexa as decisões e soluções arquitetônicas urbanísticas, livrando-as da expectativa de vínculos formais preconcebidos.

Considerando o processo histórico, seguiu-se o encaminhamento de que interpretações mais complexas podem auxiliar inclusive no desvendamento da relação entre arquitetura e capital produtivo, como propõe Tafuri. $\bigcirc$ autor, por meio de sua 
9. Ver Manfredo Tafuri $(1979,1984)$ crítica à ideologia, mesmo concluindo pela impossibilidade estrutural de uma arquitetura de vanguarda, alerta para os perigos das visões simplificadoras.

Em seus diversos ensaios sobre a relação entre as teorias e a história da arquitetura, mais especificamente em Teorias e História da Arquitetura, e em La esfera e el laberinto: vanguardias y arquitectura de Piranesi a los años setenta, faz uma crítica aos historiadores do movimento moderno, sobretudo a Giulio Carlo Argan, Leonardo Benevolo e Bruno Zevi. Para Tafuri, esses autores reafirmavam certa condução ideológica do movimento moderno, cujo desenvolvimento esteve entranhado na própria lógica da organização produtiva do capitalismo. Contrapondo-se aos autores em questão, Tafuri explicitava os vínculos do movimento moderno com a economia de capital, entendendo que, ao se propor a satisfazer as necessidades reais dos indivíduos, a arquitetura moderna teria permitido sua instrumentalização direta por parte do sistema, o que automaticamente anulava o potencial transformador contido em suas formulações. Assim, a arquitetura, ao ser "propositiva", era estruturalmente impossível como vanguarda, pois o potencial transformador das vanguardas estava em sua contraposição ao sistema. Por essa perspectiva, não havia heróis a decifrar o espírito do tempo, como preconizava a tradição hegeliana da história da arte, mas teria de se investigar a aderência da arquitetura aos processos históricos nos quais está inserida. Portanto, o papel do historiador seria revelar as contradições da arquitetura e não dar as bases para a atividade profissional, buscando no passado o certo e o errado para procedimentos projetuais. Defendia assim, a autonomia da atividade do historiador da arquitetura, não pela separação da história da arte, como reivindicava Zevi, mas pela separação entre teorias, história e prática arquitetônica, afirmando a dimensão prática do próprio "fazer histórico", a história como projeto. ${ }^{9}$

Nessa perspectiva, parecia importante verificar as realizações da arquitetura não somente a partir de seus êxitos, tampouco de seus fracassos, mas de suas contradições.

Para a análise construída, foi importante escapar das armadilhas de eleger atores, arquitetos e engenheiros específicos, ou de interpretar a arquitetura exclusivamente a partir de paradigmas formais consagrados, como aqueles usualmente atribuídos ao que se convencionou chamar de "arquitetura moderna".

Naquilo que diz respeito mais especificamente à questão habitacional, a reflexão não se propôs a discutir a produção do período estudado a partir de parâmetros de universalização de acesso à moradia, que inevitavelmente demarcariam o fracasso da iniciativa. Foram considerados os limites impostos pela condição periférica do Brasil em relação ao capitalismo mundial, e o que significou naquele momento, dos pontos de vista material e simbólico, a produção de conjuntos habitacionais de grande impacto nas principais cidades brasileiras, mais especificamente no Rio de Janeiro, então capital do país.

Seguindo Tafuri, foi inevitável admitir a aderência das ideias e dos projetos em questão ao movimento histórico da inserção do Brasil no capitalismo 
mundial. Por outro lado, para uma análise mais complexa dessa história, foi necessário relativizar as interpretações que partem apenas do viés ideológico dessa produção habitacional, entendendo-a como parte das transformações culturais que retiraram o Brasil de uma condição exclusiva de economia agroexportadora, e cujas políticas desenvolvimentistas obtiveram sucesso relativo na industrialização do país.

$\mathrm{Na}$ relação com as movimentações políticas, foi fundamental a ancoragem na bibliografia que procurou superar as interpretações mais consolidadas sobre o período, questionando a ideia de "populismo", entendido como simples manobra de massas, e procurando analisar de forma mais aprofundada o que teria sido o pacto trabalhista, entre setores da elite política e a classe de trabalhadores urbanos em formação (GOMES, 1988; DRAIBE, 1985). Esse esforço foi fundamental para a construção de uma visão que relacionasse o objeto da pesquisa a outros campos do conhecimento e que inserisse a produção da cidade - seus aspectos físicos e representativos - nas dinâmicas culturais mais abrangentes.

Já no âmbito da arquitetura e do urbanismo, revelou-se imprescindível o entendimento dos técnicos e da elite cultural como agentes singulares do processo de modernização (MARTINS, 1987; GORELIK, 2005).

Nesse sentido, a pesquisa tomou o lapi para alcançar alguns objetivos: entender a obra e o papel dos administradores, engenheiros e arquitetos de um ponto de vista histórico, considerando sua formação profissional e suas opções e escolhas de ação; considerar o papel dos técnicos na política desenvolvimentista empreendida a partir de 1930; procurar as relações entre a arquitetura e as propostas de modernização do país; analisar os aspectos materiais e construtivos da arquitetura e do urbanismo. A opção, na contramão dos caminhos que repisam os fracassos do movimento moderno no Brasil e atribuem à estética funcionalista as agruras da cidade contemporânea, foi a de recuperar projetos, obras e profissionais para a história da arquitetura brasileira. Com isso, a pesquisa permitiu a valorização de uma proposta habitacional, de suas qualidades plásticas e técnicas, em relação à formação de uma classe trabalhadora urbana. Dessa maneira, sem perder de vista as ambiguidades e as contradições que marcaram a Era Vargas, os trabalhadores urbanos emergem como agente político específico, e não como quadro meramente explorado.

Assim, o Estado deixa de ser considerado exclusivamente por seu papel de instrumento exclusivo de uma classe e passa a ser entendido como campo conflitivo, com seus espaços sendo disputados tanto pelas classes políticas tradicionais quanto pelos setores sociais urbanos que vinham em formação e consolidação desde as décadas de 1920 e 1930.

As elites culturais tiveram papel fundamental na trama sociopolítica desse período, que foi identificado como de "industrialização restringida" e que, segundo Draibe (2004), teria culminado na formação das bases técnicas indispensáveis à autodeterminação da acumulação capitalista. Grupos formados 
por intelectuais e ativistas de classe média, que abrangiam desde os mais conservadores, elitistas e positivistas, até uma variedade de grupos socialistas, defenderam conjuntamente, naquele momento, maior centralização do poder e passaram a cobrar do Estado federal um papel mais ativo na regulamentação do sistema econômico.

A perspectiva de uma sociedade urbanizada e industrializada colocava em retroalimentação as ideias do campo da arquitetura e do urbanismo e os conceitos de racionalização mais presentes na engenharia, na economia e na administração. Racionalizados deveriam ser os processos produtivos (trabalho e meios), da indústria, do setor terciário e, por conseguinte, da administração pública. Na iniciativa privada, sob a liderança de Roberto Simonsen, defendia-se o desenvolvimentismo e a intervenção do Estado. Acreditava-se que somente por meio de uma ação estatal centralizada seriam superadas as barreiras sociais e econômicas para o ingresso do país no capitalismo internacional.

A figura de Simonsen correspondia a um amplo espectro coletivo formado por outros nomes, como João Carlos Vital, Plinio Cantanhede, Alim Pedro, Ary Torres, Paulo Accioly de Sá, Eudoro Berlink, Luiz Joaquim da Costa Leite, que, entre outros, foram identificados nos documentos e artigos de periódicos levantados pela pesquisa. Tais personagens transitavam por uma série de instituições públicas e privadas com o firme propósito de viabilizar um projeto modernizador. Oscilando entre posições ora mais progressistas, ora mais conservadoras, influíram diretamente nas decisões políiticas.

Esses técnicos tinham num horizonte comum com os profissionais da arquitetura e do urbanismo - a prática do planejamento. Assim, o conceito de planejamento vinculado à ideia de eficiência própria do campo da engenharia aparecia tanto como instrumento de política econômica, que apontava para uma orientação nacional desenvolvimentista, quanto para a organização das bases físicas da vida social na forma da cidade total. Nesse sentido, o lapi transformouse também em paradigma das ideias de eficiência e de isenção técnica, tendo sido o primeiro órgão público no Brasil a realizar um grande concurso para a provisão de cargos para suas delegacias em todo o país. $\bigcirc$ documento intitulado A criação e a organização do lapi, de 1939, infundiu critérios técnicos e meritocráticos e acabou por conformar um imaginário dos preceitos que moviam a ação do Instituło (INSTITUTO DE APOSENTADORIA E PENSÕES DOS INDUSTRIÁRIOS, 1939).

Em 1940, a publicação que trazia um balanço das atividades do lapi desde sua implantação fazia referência àquele documento fundador, buscando enfatizar a promoção do desenvolvimento econômico e social pela ação da previdência, relacionando-a a uma organização administrativa pautada nas ideias de especialidade e de eficiência. Nesses documentos, as palavras "honestidade", "discernimento" e "exação" eram enunciadas como instrumentos, na mesma categoria que outras, como "precisão" e "regularidade", informando 
como características individuais e subjetivas eram vistas de forma inerente aos procedimentos técnicos. O lapi orgulhava-se de seu pioneirismo:

Graças à Comissão Organizadora do lapi, pela primeira vez na história de nossas repartições governamentais tiveram os problemas de administração geral tratamento sistematizado e objetivo, à luz dos modernos ensinamentos da ciência e da técnica administrativas.

$[\ldots]$

Nasceu, por certo, do exemplo dessa notável equipe de técnicos da Comissão Organizadora o impulso criador da honrosa tradição que coloca o lapi como vanguardeiro na prática dos bons métodos de administração científica. (PEDRO, 1950, p. 385)

lapi foi local privilegiado para a estratégia que imputava no conceito de eficiência a suposta isenção política da ação dos técnicos. Por meio do debate sobre os conceitos de eficiência e racionalização abriu-se a janela para a predominância dos engenheiros em certos setores do serviço público, cujo próprio discurso de legitimação da profissão levou-os a ocupar espaços que iam muito além de seu campo de atuação original.

Os documentos auxiliaram na leitura do papel dos profissionais, engenheiros e arquitetos, no processo de urbanização, não como meros condutores de determinadas ideologias, mas como agentes tanto da ampliação de seu campo de atuação, como da possível transformação nas bases materiais da vida dos trabalhadores.

Algumas diretrizes que podem ser identificadas ao analisar a localização, a implantação e a construção dos conjuntos residenciais do Instituto estavam explicitadas em relatório de atividades publicado no ano de 1940, que trazia as orientações para a aquisição de terrenos destinados aos investimentos de caráter social, nos quais deveriam predominar os fatores de ordem técnica e econômica:

a. facilidade e economia de transporte de preferência ferroviário;

b. boas condições de salubridade e boa conformação topográfica;

c. proximidade dos centros industriais ou fácil acesso aos mesmos;

d. baixo custo unitário do terreno, de forma que os conjuntos residenciais operários possam ser planejados dentro dos princípios da técnica urbanística. (INSTITUTO ..., 1941, p. 90)

Nesse mesmo documento (Figura 9), já apareciam as referências internacionais de maneira incisiva e institucional, revelando que as novas concepções foram acionadas diretamente pela burocracia estatal, desde o princípio da organização do lapi:

A orientação adotada pelo Instituto não representa inovação. As cidades-jardins operárias de Lechworth e Welwyn na Inglaterra, as grandes construções populares nos arredores de Paris e Roma, as cidades europeias alemãs como as de Siemensstadt e Hasehorst, para só citar as mais importantes, indicam a solução mais racional para o problema. $\bigcirc$ esforço dos Estados Unidos, nos últimos anos, através da obra da Federal Housing Administration, é notável. As chamadas cidades de orla Verde, das quais três já estão sendo construídas: Greenbellt no

Annals of Museu Paulista. v. 24. n.3. Sept.-Dec. 2016. 
Maryland, Grenhills em Ohio e Greendale no Wisconsin, demonstram que a solução geral do problema do lar das classes economicamente fracas só pode ser encontrada na construção em larga escala e em áreas que permitam a formação de centros urbanos em condições de vida própria. (INSTITUTO..., 1941, p. 91)
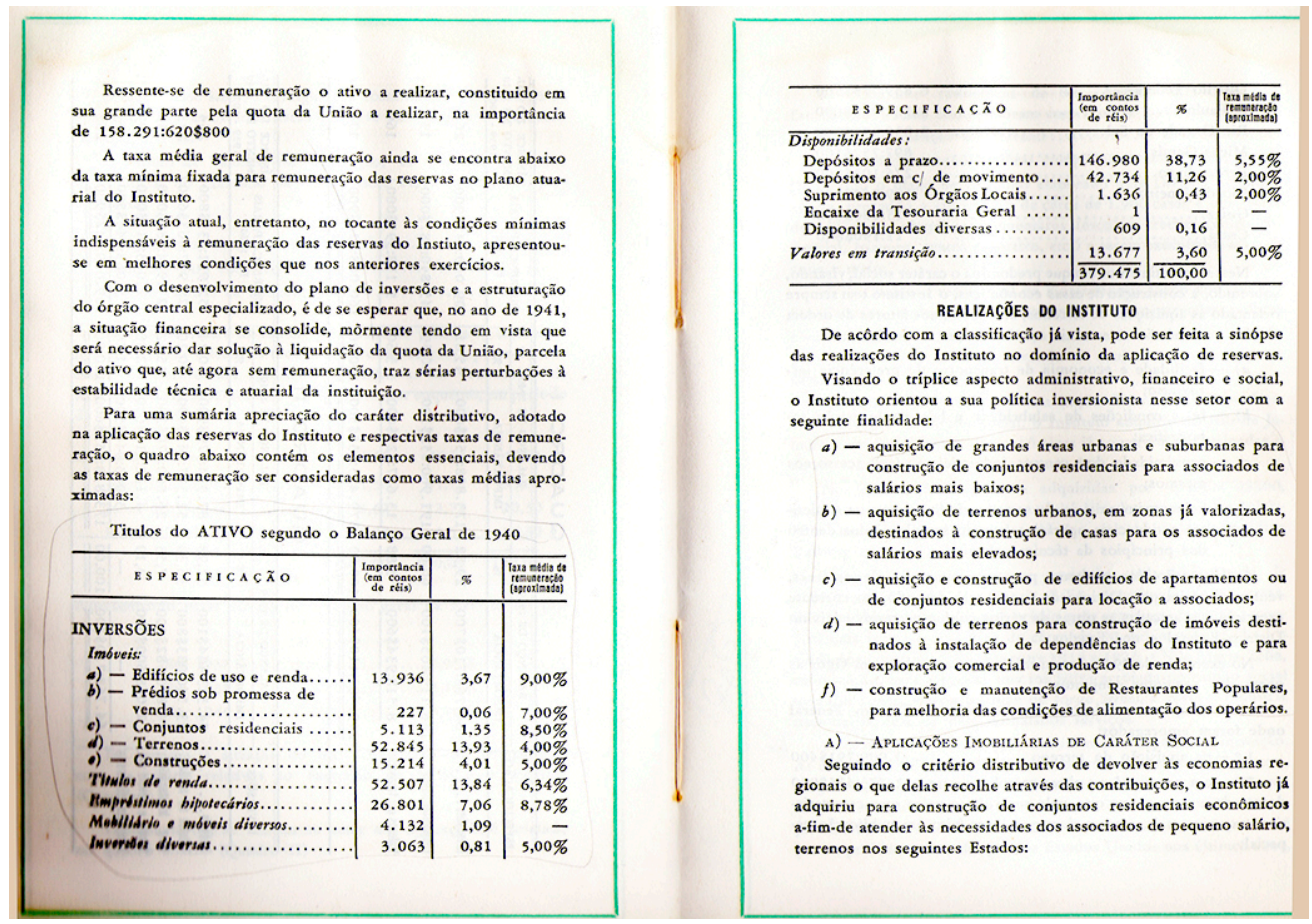

Figura 9 - Página de documento do lapi publicado em 1941, intitulado Relatório e Balanço Geral de 31 de dezembro de 1940 (3 Exercício) (INSTITUTO..., 1941, p. 90-91). Em destaque as diretrizes de ação imobiliária do Instituto. Fonte: Acervo pessoal da autora.

texto desse relatório foi assinado por Plínio Cantanhede, então presidente do Instituto. Por meio de publicações para a divulgação das atividades do lapi, as ideias sobre habitação apareciam de forma destacada e as referências internacionais serviam para legitimar a iniciativa do Instituto de produzir habitação. Apontava-se, no entanto, a ressalva de que tais referências, que se apresentam as mais variadas, não poderiam ser tomadas em sua integridade, devendo-se atentar para a necessidade de adaptação às condicionantes nacionais. Principalmente era necessário ter em conta o problema econômico:

Infelizmente, as nossas condições de vida e o baixo poder aquisitivo do salário dos nossos operários não permitem realizações de tal vulto, com tais requintes construtivos. A adaptação desses princípios, guardadas as devidas proporções para o nosso meio, é a única forma de solucionar o problema.

$[\ldots]$ 
Não levar em conta os fatores essenciais técnicos e, principalmente, econômicos é deslocar - problema do plano real, passível de execução, para o campo da utopia, elegante e fácil de esboçar nas conferências e em artigos de jornal. (INSTITUTO..., 1941, p. 92)

Mas, ao ater-se ao campo do "passível de execução", não se perdia de vista a ideia de habitação em sua integralidade, como serviço público a ser oferecido aos associados:

Em poucas linhas, um técnico francês, Maurice Rotival, resume a questão que hoje em dia é de capital importância para a solução dos problemas sociais que agitam a civilização: "Construir habitações econômicas é fazer ao mesmo tempo e necessariamente - urbanismo. Parece inconcebível a construção de edifícios cujos princípios essenciais têm sua origem em ideias de bondade e solidariedade humana, como é inacreditável que a aplicação de novas regras de higiene, sem prever, ao mesmo tempo, espaços livres, creches, escolas, campos de esportes, prados infantis, piscinas, que devem fazer parte de qualquer plano de conjunto. Construir habitações econômicas, dividindo-as em pequenos lotes disseminados na massa das construções urbanas - é agravar o mal, é retrogradar". (INSTITUTO..., 1941, p. 92)

Na esfera da administração pública, os agentes executavam seu trabalho a partir da articulação entre os debates do campo disciplinar e o projeto político do país.

As peças gráficas e os levantamentos de campo comprovaram que a ação do Instituto de Aposentadoria e Pensões dos Industriários, considerada tanto por sua dimensão quantitativa, quanto pelo conceito de habitação em massa formulado por seus técnicos, tornou-se o principal órgão responsável pela produção habitacional pública no período estudado. Ao cotejar os documentos do Instituto, os artigos de periódicos e seu confronto com as obras construídas, foi possível deduzir que a adequação entre quantidade e qualidade foi o que ofereceu as condições para que o órgão atingisse certo destaque diante de toda a produção do período (BONDUKI; KOURY, 2014). ${ }^{10}$

Pode-se dizer que, por colocar a economia como condicionante básica dos projetos, o lapi reuniu condições para superar o universo de exceção ao qual se enquadraram as experiências de Affonso Eduardo Reidy e Carmem Portinho junto ao Departamento de Habitação Popular do Rio de Janeiro. Além disso, estava muitíssimo à frente da produção acanhada da Fundação da Casa Popular, restrita aos conjuntos de casas isoladas voltadas à aquisição privada. Não se pode deixar de considerar aqui que a orientação da produção para o aluguel estava diretamente associada aos preceitos atuariais, que prezavam pelos interesses em resguardar o capital dos associados do Instituto, o que também pôde-se comprovar pela documentação (Figura 10).

Veja-se, neste ponto, que o motor da excepcionalidade da ação do lapi também o levou a diminuir drasticamente, até a estancar de vez, a produção habitacional no início da década de 1950. A Lei do Inquilinato inviabilizou a rentabilidade com o aluguel depois de 1942 e, se no início, o
10. Tal distinção pode ser constatada a partir da observação do "Inventário da produção pública no Brasil entre 1930 e $1964 "$ (BONDUKI; KOURY, 2014, v. II) 
seu congelamento era percebido como uma saída provisória para crise da habitação, a ação se revelaria permanente com os sucessivos decretos e leis complementares, por duas décadas depois (BONDUKI, 1998, p. 217-218). A rentabilidade cada vez menor com os imóveis habitacionais ainda coincidiu com o grande aumento do número de associados ao Instituto /se no início contava com 1 milhão de associados, é fácil supor que dez anos depois tivesse ao menos o dobrol. Não cabia na lógica atuarial favorecer a $1 \%$ dos associados com moradias baratas, ao passo que se arriscava a seguridade da aposentadoria para os outros $99 \%$.

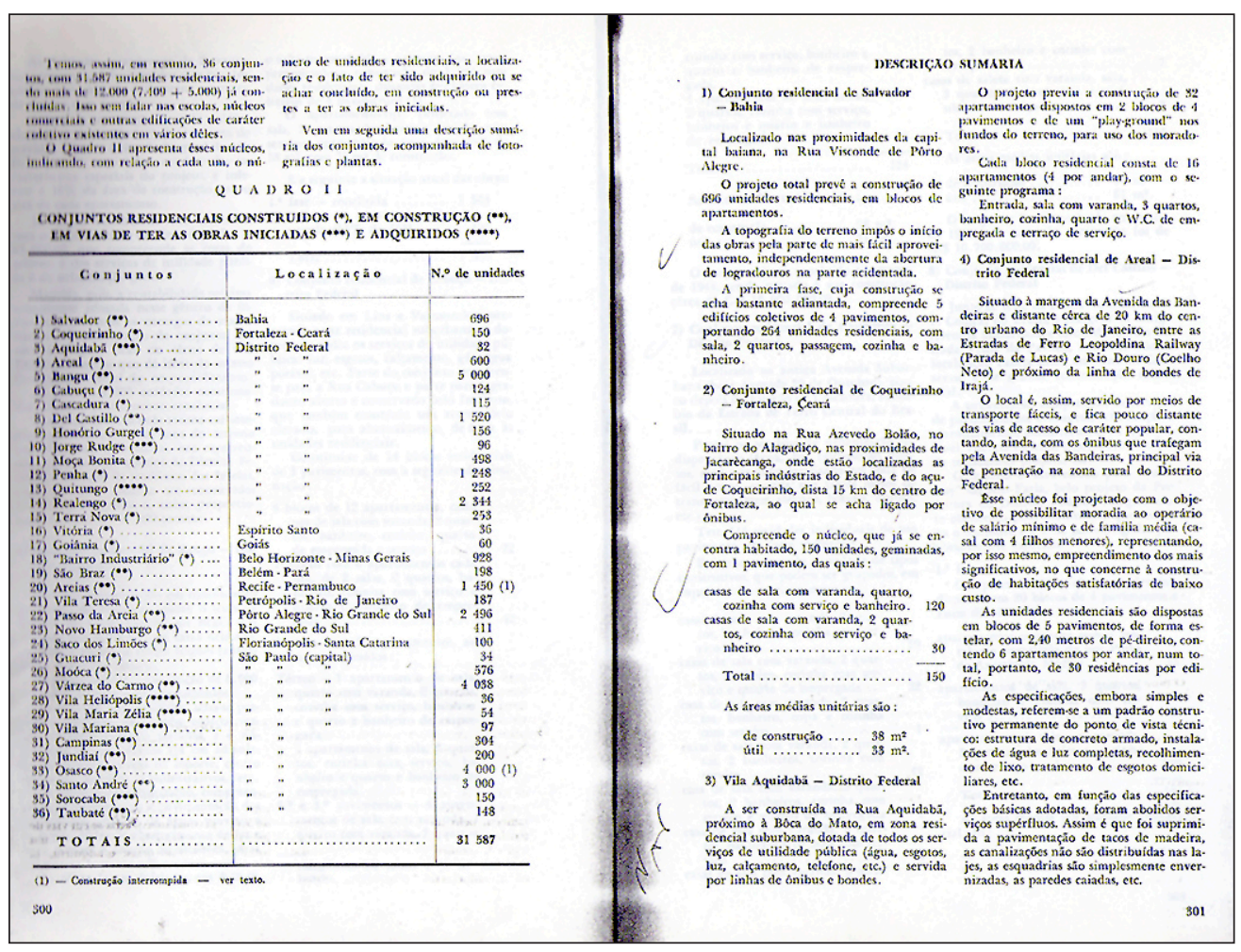

Figura 10 - Página de documento do lapi, assinado pelo presidente do Instituto em exercício, Alim Pedro, publicado em 1950 e intitulado O seguro social, a indústria brasileira, o Instituto dos Industriários. Relatório-estudo do presidente do lapi, período de 1946 a 1951 . Em destaque, o balanço da produção habitacional do lapi até a data da publicação. Fonte: Acervo pessoal da autora.

A partir do diálogo entre as fontes documentais e o método interpretativo também se encontrou a explicação tanto para o vanguardismo da ação habitacional do lapi, quanto sua derrocada a partir de 1950. No processo de transformação que coloca o Brasil de vez no sistema capitalista, entende-se a Revolução de 1930 e os acontecimentos subsequentes como uma ruptura de certos esquemas políticos, econômicos, sociais e culturais. A partir da aceitação desse momento como ruptura é que se procurou situar o entendimento de um 
determinado conceito de habitação, de arquitetura e de cidade. Se na década de 1940 foi fundamental assegurar moradia aos associados, impulsionar a indústria da construção civil e demarcar o território metropolitano, na década de 1950 a passagem para a fase da industrialização pesada demandava a canalização de recursos para a indústria, e a progressividade da Lei do Inquilinato funcionou também para isso. A partir da documentação existente, ao colocar em linha cronológica a produção do lapi, vê-se que a gradativa diminuição das atividades de construção de conjuntos habitacionais no período coincide com a intensa participação estatal na consolidação definitiva do capitalismo no Brasil, e o prenúncio dos elementos de esgotamento e crise do Estado identificados por Draibe (2004, p. 237-239).

Por outro lado, no que diz respeito às relações com a cultura, o levantamento extensivo da produção pública de habitação do período que vai de 1930 a 1964 abriu um leque de conjecturas que não podiam mais se valer das matrizes interpretativas que alicerçaram a trama canônica da história da arquitetura brasileira. A maioria dos conjuntos produzidos pelos institutos, com destaque para o lapi, passava ao largo dos cinco pontos da arquitetura moderna definidos por Le Corbusier, mesmo nas experiências de maior racionalização, como nos casos dos conjuntos do Realengo e da Penha (Figuras 1 1, 12 e 13). Essa constatação exigiu um esforço para construir uma nova base teórica, buscando encontrar outras possíveis conexões do objeto, para além da referência corbusiana e mesmo europeia. Assim, abriu-se o caminho para as pontes com as ideias cientificistas em geral, e mais ainda, com o pragmatismo e o progressivismo norte-americanos. Noções como as de eficiência e de organização, cuja importância crescente na primeira metade do século XX confluiu para a reestruturação de alguns setores da indústria, passou pelas organizações educativas e chegou às instâncias governamentais, tornando-se o grande mote da cadeia comunicativa entre Estado e setor privado. A engenharia, num processo de legitimação bastante satisfatório, mostrou-se ser a disciplina mais capacitada e permeável numa sociedade que deveria ser pautada pela técnica.

A partir do acervo geral do Grupo Pioneiros, o recorte sobre a produção habitacional do lapi buscou entender, portanto, a heterogeneidade dos resultados arquitetônicos e urbanísticos em toda a sua complexidade, inclusive desvelando, em suas aparentes sínteses, as ambiguidades próprias da sociedade brasileira. Ao estabelecer uma relação dialética entre a profusão das fontes e os procedimentos de análise é que foi possível afinal pensar a revisão de uma parte da história da habitação no Brasil, primando pela necessidade de divisar o objeto específico em sua relação com o todo, seja no âmbito da história da arquitetura, seja nos grandes panoramas que buscam identificar o papel do Brasil nos processos de consolidação do sistema capitalista. 


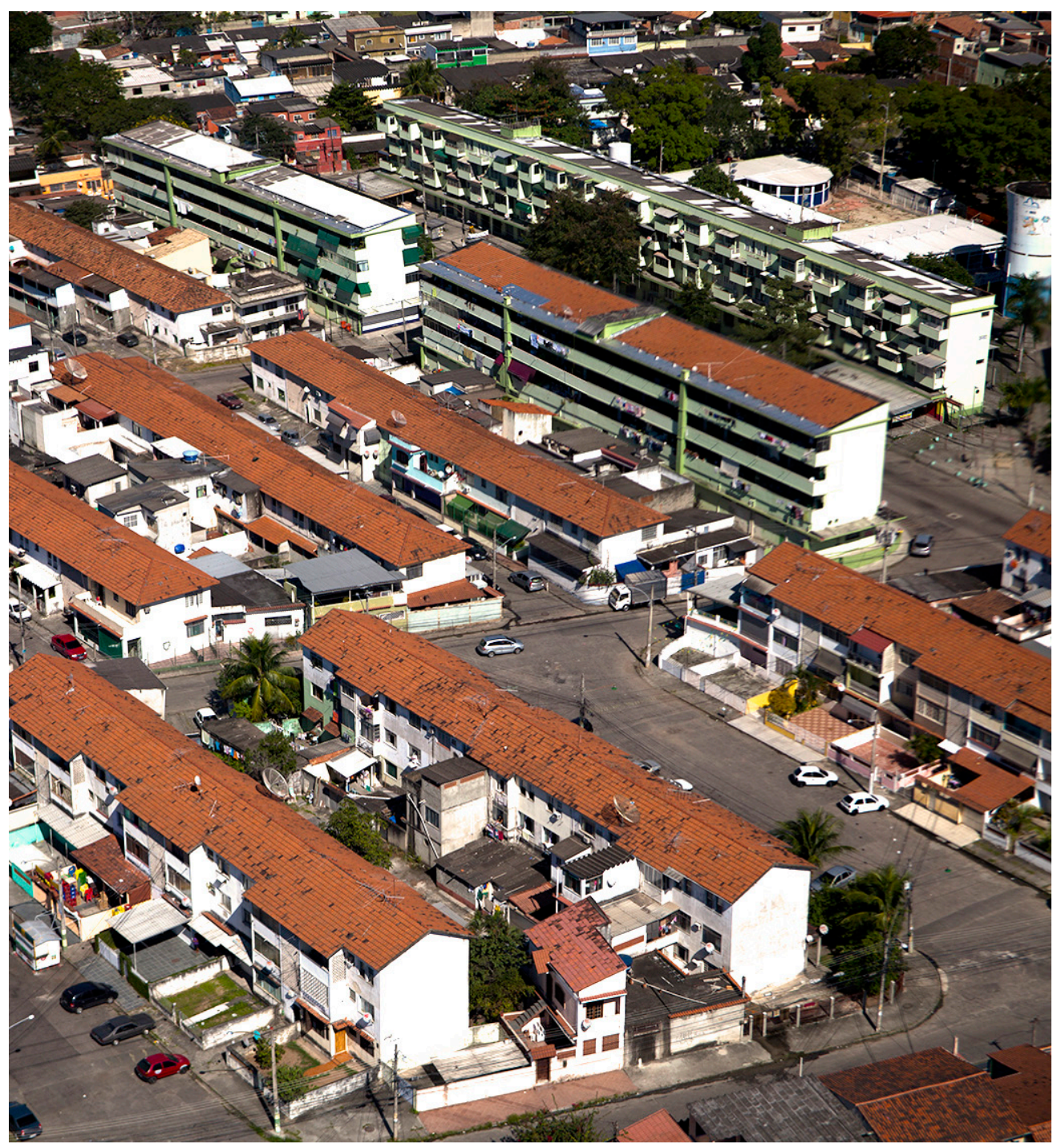

Figura 11 - Conjunto Residencial Operário em Realengo, Rio de Janeiro. $O$ conjunto, projetado pelo arquiteto Carlos Frederico Ferreira, foi o primeiro de grande porte realizado pelo setor público no Brasil. É conformado por diversos tipos habitacionais, desde casas isoladas no lote até esses blocos de habitação coletiva, em destaque na imagem aérea. Fonte: Acervo do Grupo Pioneiros. 
Figuras 12 e 13 (próxima página) Conjunto Residencial da Penha, Rio de Janeiro. As duas imagens aéreas colocam em destaque a implantação dos edifícios de habitação coletiva em meio ao parcelamento mais tradicional ocupado por casas unifamiliares. As caixas-d'água para abastecimento do conjunto representaram a presença física e simbólica do Estado na paisagem, até então dominada pelo referencial católico da lgreja da Penha no alto do morro. Fonte: Acervo do Grupo Pioneiros da Habitação Social.

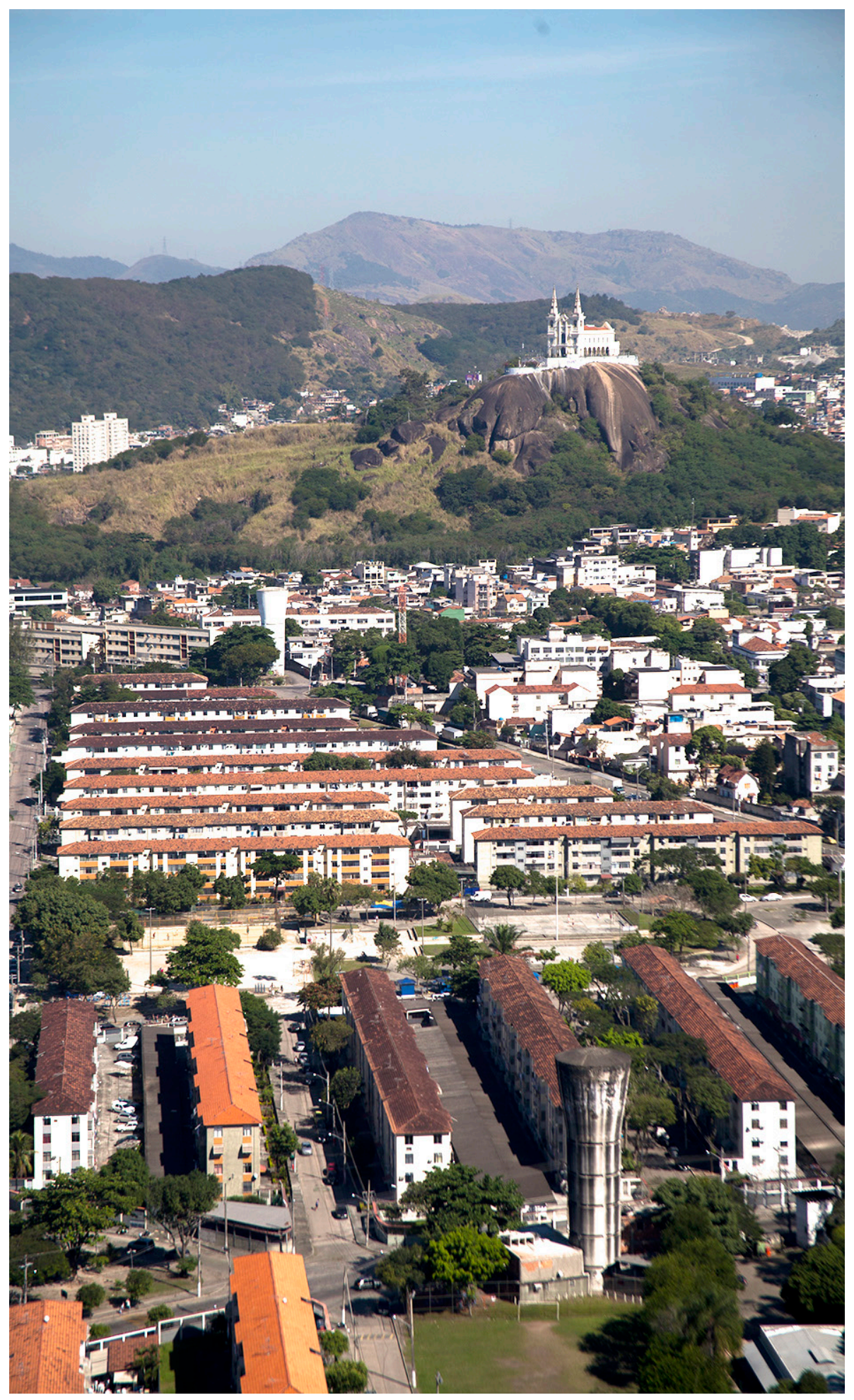




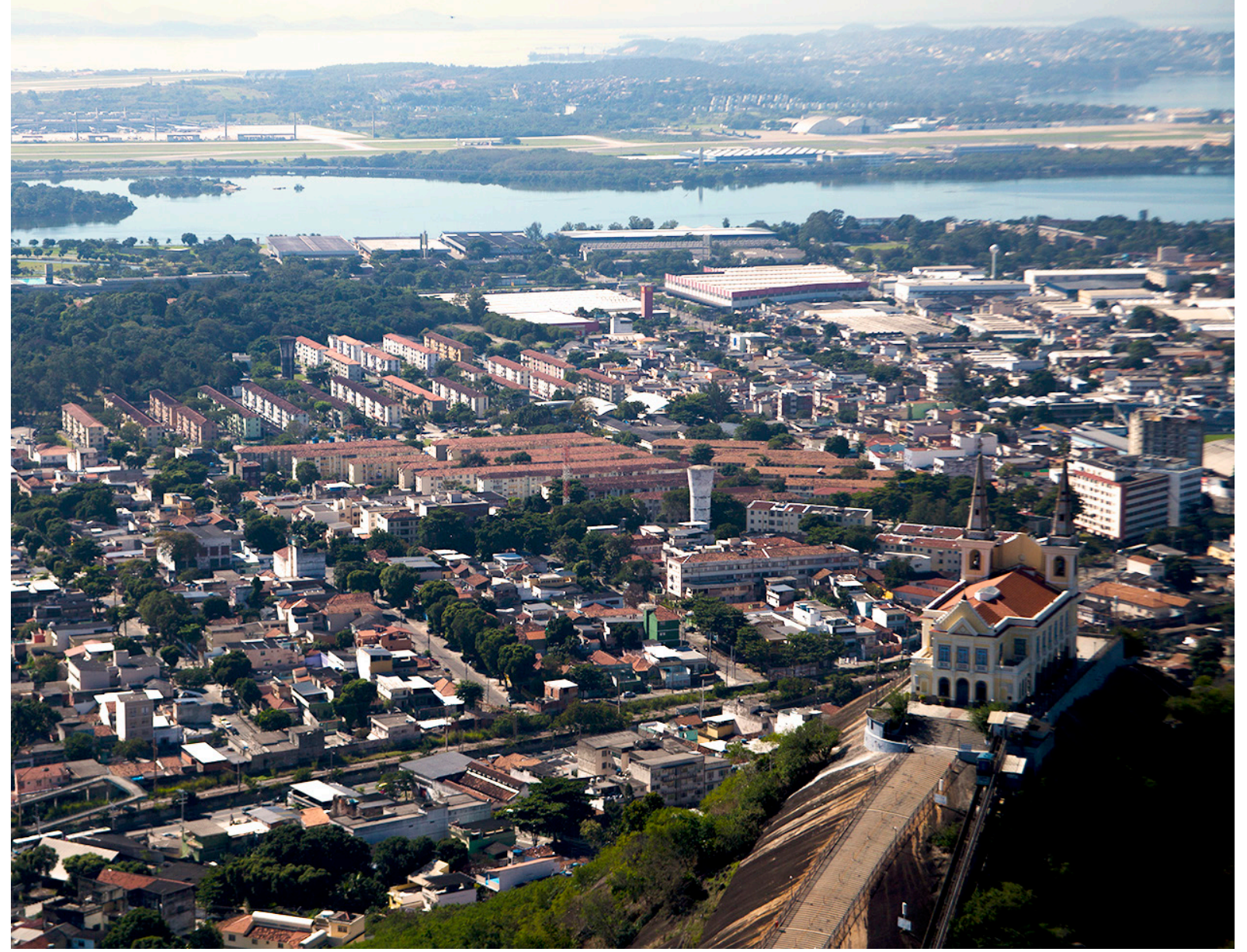

Figura 13 - Conjunto Residencial da Penha, Rio de Janeiro 


\section{REFERÊNCIAS}

ARAVECCHIA-BOTAS, Nilce Cristina. Realengo. In: BONDUKI, Nabil; KOURY, Ana Paula (Orgs). Os pioneiros da habitação social no Brasil. São Paulo: Edunesp; Sesc, 2014. p. 6-40.

Entre o progresso técnico e a ordem politica: arquitetura e urbanismo na ação habitacional do Iapi. 2011. Tese (Doutorado) - Faculdade de Arquitetura e Urbanismo, Universidade de São Paulo, 2011.

Habitação social no Rio de Janeiro e as contribuições e influências de Carlos Frederico Ferreira e Rubens Porto. Relatório de iniciação científica apresentado à Fapesp. Departamento de Arquitetura e Urbanismo, Escola de Engenharia de São Carlos, Universidade de São Paulo, 2000.

; KOURY, Ana Paula. A cidade industrial brasileira e a política habitacional na Era Vargas (1930-1964). Dossiê: Cidade e Habitação na América Latina. Revista Urbana. Campinas, CIEC/Unicamp, v. 6, n. 8, p. 143-165, jun. 2014.

; NASCIMENTO, Flávia B. Penha. In: BONDUKI, Nabil; KOURY, Ana Paula (Orgs). Os pioneiros da habitação social no Brasil. São Paulo: Edunesp; Sesc, 2014. p. 194-216.

BLOCH, Marc. Apologia da história. Tradução por André Telles. Rio de Janeiro: Jorge Zahar, 2002.

BONDUKI, Nabil Georges. Origens da habitação social no Brasil: arquitetura moderna, Lei do Inquilinato e difusão da casa própria. São Paulo: Estação Liberdade, 1998.

Habitação social no Brasil: uma história em construção. In: ENCONTRO DA ASSOCIAÇÃO NACIONAL DE PROGRAMAS DE PÓS-GRADUAÇÃO E PESQUISA EM PlANEJAMENTO URBANO E REgIONAL, 7., 1999, Porto Alegre. Anais...Porto Alegre: Enanpur, 1999.

; KOURY, Ana Paula (Orgs). Os pioneiros da habitação social no Brasil. São Paulo: Edunesp; Sesc, 2014.

DRAIBE, Sonia. Rumos e metamorfoses - Estado e industrialização no Brasil (1930-1960). São Paulo: Paz e Terra, 2004.

FEBVRE, Lucien. Combates pela história. Tradução de Leonor Martinho Simões e Gisela Moniz. Lisboa: Editorial Presença, 1977.

GOMES, Angela de Castro. A invenção do trabalbismo. São Paulo: Vértice, 1988.

GORELIK, Adrián. Das vanguardas a Brasília. Cultura urbana e arquitetura na América Latina. Tradução de Maria Antonieta Pereira. Belo Horizonte: Editora UFMG, 2005.

INSTITUTO DE APOSENTADORIA E PENSÕES DOS INDUSTRIÁRIOS. A criação $e a$ organização do Iapi. Rio de Janeiro: Tipografia Mercantil, 1939. 
Relatório e Balanço Geral de 31 de dezembro de 1940 ( $3^{\circ}$ Exercício). Rio de Janeiro: Tipografia Mercantil, 1941.

LE GOFF, Jacques. A história nova. Tradução de Eduardo Brandão. São Paulo: Martins Fontes, 1990.

MARTINS, Carlos Alberto Ferreira. Arquitetura e Estado no Brasil. Elementos para uma investigação sobre a constituição do discurso moderno no Brasil; a obra de Lucio Costa (19241952). 1987. Dissertação (Mestrado) - Faculdade de Filosofia, Letras e Ciências Humanas, Universidade de São Paulo, 1987.

PEDRO, Alim. O seguro social, a indústria brasileira, o Instituto dos Industriários. Relatórioestudo do presidente do Iapi, período de 1946 a 1951. Rio de Janeiro: Iapi, 1950.

TAFURI, Manfredo. Teorias e História da arquitetura. Tradução de Ana Brito e Luis Leitão. Lisboa: Editorial Presença, 1979.

La esfera e el laberinto: vanguardias y arquitectura de Piranesi a los años setenta. Tradução para o espanhol de Fracesc Serra Cantarell. Barcelona: Gustavo Gilli, 1984. 